\title{
Accountingvernieuwing als wolf in schaapskleren
}

\author{
Jan van Helden
}

We kennen allemaal de verhalen over manipulatie van accountingcijfers om de zaken anders voor te stellen dan overeenkomt met de werkelijkheid. Dan komen ons affaires als die van Enron en Ahold voor de geest, waarbij door verdraaiing en verzwijging van essentiële accoun-

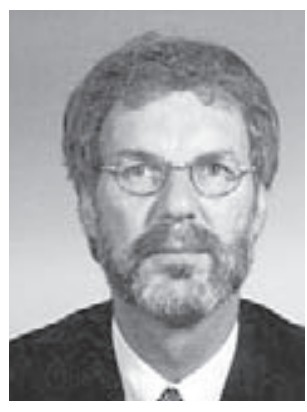
tinginformatie ondernemings-

resultaten rooskleuriger werden voorgespiegeld dan ze waren. Een nieuwe loot aan deze boom van misbruik van accountinginformatie komt uit de overheidssector in Nieuw-Zeeland. De helaas te vroeg overleden June Pallot en haar co-auteur Susan Newberry zien een soort verborgen agenda achter de accountingvernieuwingen die de publieke sector in hun land gedurende de laatste twintig jaren heeft doorgemaakt ${ }^{1}$.

Uit de analyse van Newberry en Pallot blijkt dat de Nieuw-Zeelandse overheid zich bedient van een hardvochtig budgettair beleid. Zo werden jaren achtereen kortingen op de departementsbegrotingen doorgevoerd onder het mom van 'efficiency dividends' en achterwege blijvende prijscompensaties. Daarnaast moesten departementen eventuele financiële overschotten inleveren bij de minister van Financiën, terwijl ze tekorten zelf maar moesten zien 'in te verdienen'. Door dit beleid is het publieke domein verkleind, waardoor de dienstverlening van de overheid aan het publiek is verslechterd of deze dienstverlening (deels) door private aanbieders is overgenomen.

Verder heeft de toepassing van het batenlastenstelsel

Prof. Dr. G.J van Helden is hoogleraar management accounting aan de Economische Faculteit van de Rijksuniversiteit Groningen. ('accrual accounting') sterk bijgedragen aan privatisering van overheidstaken. Specifieke wetgeving zette overheidsdiensten namelijk op achterstand van het bedrijfsleven. Zo werd prijszetting van overheidsdiensten onder de kostprijs verboden en werden deze diensten verplicht om bij de berekening van investeringslasten de vervangingswaarde van activa als waarderingsgrondslag te hanteren. Het bedrijfsleven heeft bij de accounting veel grotere vrijheidsgraden, waardoor via competitieve kostprijsberekening en prijszetting goede perspectieven ontstonden om de overheid bepaalde diensten 'af te pakken'.

Ook publiek-private samenwerking (PPS) is aan Nieuw-Zeeland niet voorbijgegaan. Samenwerkingsverbanden tussen overheid en bedrijfsleven werden opgezet om infrastructurele projecten met een lange levensduur, zoals een brug, weg of haven, mogelijk te maken. Aangezien de investeringen in dergelijke projecten buiten de overheidsbalans bleven, kreeg de overheidschuld - althans optisch gezien - een rooskleuriger aanzien. Een extra impuls voor PPS-constructies ontstond doordat deze niet zijn onderworpen aan bepaalde verslaggevingseisen, zoals verantwoording over latente verplichtingen. Hierdoor onttrekken dergelijke financieringsconstructies zich ook aan parlementaire toetsing.

In meer algemene zin hekelen Newberry en Pallot de uitholling van de oordeelsvormende functie van het Nieuw-Zeelandse parlement. De hoeveelheid informatie waarover het parlement beschikt, is weliswaar in de loop der jaren sterk toegenomen, de tijd om daarover te beraadslagen en een oordeel te vormen, is echter drastisch gereduceerd. Dat geldt zowel voor de begroting als de rekening van de centrale overheid. Deze beoordelende functie van het parlement wordt verder verminderd door recente wetgeving die het mogelijk maakt financiële informatie over producten te aggregeren tot productgroepen. 
In de ogen van Newberry en Pallot vervult de accountingfunctie in de overheidssector een ruimere rol dan in de private sector. In de publieke sector moet de accountingfunctie de belastingbetalers via hun parlementaire vertegenwoordigers zeggenschap en controle bieden over de besteding van overheidsmiddelen. Dat vereist transparantie, niet als modewoord, maar als beginsel van inzichtelijkheid in de financiële gevolgen van allerhande transacties.

Wat kunnen we van dit type analyses leren voor de Nederlandse situatie? Deze vraag laat zich via een tweetal invalshoeken beantwoorden: bezien vanuit de praktijk van politiek en overheidsmanagement en met een meer wetenschappelijke blik.

Hoewel Nieuw-Zeeland in verschillende opzichten een radicaler veranderingsspoor heeft bewandeld dan Nederland - met in ons land een minder geprononceerd privatiseringsbeleid en een beleid van markttoetsing voor overheidsdiensten - moeten de waarschuwingen van Newberry en Pallot ook bij ons niet aan dovemansoren zijn gericht. De veranderingen in de accounting en het management bij de overheid hebben het voor leken-politici niet altijd gemakkelijker gemaakt. Het denken in kasgrootheden gaat menigeen nu eenmaal makkelijker af dan dat in termen van baten en lasten. Daarnaast raken sommige, wellicht politiek gevoelige uitgaven (voor bijvoorbeeld het inhuren van externe consultants of voor het doen van representatie) verhuld in integrale kostprijzen van producten. Hoewel ook vroeger de financiële beschouwingen graag werden overgelaten aan een selecte groep van geïnteresseerde (en hopelijk enigszins deskundige) politici, zal dat nu niet veel anders zijn. Idealiter moeten degenen die geroepen zijn te oordelen, dat ook kunnen. Parlementsleden moeten daarom beschikken over kennis van begrotings- en rekeningstechniek, of ze moeten op zijn minst kunnen terugvallen op deskundige bijstand die onafhankelijk opereert van de organen die worden gecontroleerd. In de woorden van Newberry en Pallot (p. 275): 'Contrary to the statement made by the Minister of Finance... we conclude that overlooking the political implications is a risk, especially if New Zealand is to 'set the world benchmark for public management' and that politicians need to be educated in accounting matters and their significance for the democratic process. A wolf (risk to tax payer funds) appears to entering the New Zealand government using innocuous sheep's clothing (technical accounting matters)'.

Het betoog van Pallot en Newberry laat zich ook lezen als een voorbeeld van kritisch accountingonderzoek.
Dit is een stroming van accountingonderzoek die in Nederland, voorzover ik weet, vrijwel geen aanhang geniet. In vooral Engeland is er een klein doch select gezelschap van onderzoekers die geïnteresseerd zijn in de maatschappelijke betekenis van accounting. Die blijkt lang niet altijd neutraal te zijn. Soms - of zelfs vaak, zo denken deze onderzoekers - wordt accounting gebruikt om machtsposities te versterken, mythen te ondersteunen, of meningsverschillen tussen belanghebbenden te maskeren. Kritische accountingonderzoekers, die vooral in het tijdschrift Critical Perspectives on Accounting hun forum hebben gevonden, zijn erop uit deze vormen van 'accountingmisbruik' aan de kaak te stellen. Dat doen Pallot en Newberry ook met hun analyse van het Nieuw-Zeelandse model. Zo bepleiten zij dat over de omvang van het private en publieke domein in een maatschappij een (politieke) discussie moet plaatsvinden die over de zaak zelf gaat en die niet wordt vertroebeld door een technocratische mist van complexe accountingtechnieken. Daar kan niemand tegen zijn. Of juist wel, want sommigen vinden het misschien 'slim' om fundamentele discussies te maskeren met het jargon van deskundigen. Accountingdeskundigen bijvoorbeeld.

Toch is een nuancering bij dit alles op zijn plaats. In de hier besproken analyse wordt het gebruik van accounting geassocieerd met een verborgen agenda. Dat duidt op moedwil. Zo erg hoeft het echter niet te zijn. De realisering van een bepaald politiek doel, zoals privatisering van overheidsdiensten, kan worden versterkt door specifieke accountingsystemen, terwijl deze accountingsystemen met een veel nobeler doel - zoals verbetering van informatie - zijn geïntroduceerd. Dan is dus, in plaats van moedwil, veeleer sprake van coïncidentie. Maar ook al is het een coïncidentie, we zijn wel gewaarschuwd.

\section{Noot}

1 Susan Newberry en June Pallot (2005), A Wolf in Sheeps' Clothing? Wider Consequences of the Financial Management System of the New Zealand Central Government, in: Financial Accountability and Management, Jrg. 21, nr. 3, pp. 263-275. Susan Newberry en June Pallot (2005), New Zealand Public Sector Management and Accounting Reforms: the Hidden Agenda, in: J. Guthrie, C. Humphrey, O. Olson en L. Jones (eds.) (2005), International Public Financial Management Reform: Progress, Contradictions and Challenges, InformationAge Press, USA, pp. 169-193. 